\title{
PENGARUH KUALITAS PRODUK, HARGA, PROMOSI, DAN DISTRIBUSI TERHADAP KEPUTUSAN PEMBELIAN PRODUK SANITARY WARE TOTO DI KOTA DENPASAR
}

\author{
Made Fajar Fernando ${ }^{1}$ \\ Ni Made Asti Aksari² \\ ${ }^{1,2}$ Fakultas Ekonomi dan Bisnis Universitas Udayana, Bali, Indonesia \\ e-mail: fajarfrnndo@gmail.com
}

\begin{abstract}
ABSTRAK
Perkembangan dalam dunia bisnis sanitary sangat pesat. Berbagai inovasi dan teknologi modern digunakan oleh berbagai merek sanitary ware. Toto merupakan sebuah merek produk sanitary ternama di dunia yang menjadi salah satu pelopor yang menggunakan teknologi modern dan mesin yang canggih dalam memproduksi barang-barangnya. Penelitian ini bertujuan untuk mengetahui pengaruh kualitas produk, harga, promosi, dan distribusi secara parsial dan simultan terhadap keputusan pembelian Sanitary ware merek Toto di Kota Denpasar. Jumlah sampel yang digunakan dalam penelitian ini adalah 100 responden dengan teknik purposive sampling. Data dianalisa menggunakan analisis regresi linear berganda. Berdasarkan hasil penelitian, diperoleh bahwa bauran pemasaran yang terdiri dari produk, harga, promosi, dan distribusi secara simultan berpengaruh terhadap keputusan pembelian produk sanitary ware Toto di Kota Denpasar. Secara parsial, produk, harga, promosi, dan distribusi berpengaruh positif dan signifikan terhadap keputusan pembelian produk sanitary ware Toto di Kota Denpasar. Dengan demikian dapat disimpulkan bahwa bauran pemasaran berpengaruh terhadap keputusan pembelian produk sanitary ware Toto di Kota Denpasar.
\end{abstract}

Kata kunci: kualitas produk, harga, promosi, distribusi, keputusan pembelian

\begin{abstract}
Development in the sanitary business world is very rapid. Various innovations and modern technologies are used by various brands of sanitary ware. Toto is a world leading sanitary brand that became one of the pioneers who use modern technology and advanced machinery in producing its goods. This study aims to determine the effect of product quality, price, promotion, and distribution partially and simultaneously on purchase decision of Toto Sanitary ware in Denpasar. By using purposive sampling technique, the number of samples used in this study is 100 respondent. Data were analyzed using multiple linear regression analysis. Based on the results of the study, it is found that the marketing mix consisting of product, price, promotion, and distribution simultaneously influence the purchase decision of Toto sanitary ware product in Denpasar. While partially, product, price, promotion, and distribution have positive and significant influence on the decision of purchasing Toto sanitary ware product in Denpasar. Thus it can be concluded that the marketing mix affects the purchase of Toto sanitary ware products in Denpasar.
\end{abstract}

Keyword: product quality, price, promotion, distribution, purchase decision 


\section{PENDAHULUAN}

Pesatnya perkembangan dunia bisnis saat ini membuat persaingan semakin ketat sehingga menuntut produsen untuk lebih peka, kritis dan reaktif terhadap berbagai perubahan dalam lingkungan bisnis. Perusahaan harus bekerja keras membuat kebijakan-kebijakan strategis baru dalam menjual produk dan jasa. Setiap perusahaan harus berupaya menghasilkan barang dan jasa yang diinginkan konsumen dengan harga yang pantas. Pemahaman terhadap perilaku konsumen pada setiap pasar sasaran sangatlah penting, karena kelangsungan hidup perusahaan sebagai organisasi yang berusaha memenuhi kebutuhan dan keinginan para konsumen sangat tergantung pada perilaku konsumennya (Tjiptono, 2008).

Persaingan antar perusahaan adalah suatu hal yang lazim dalam dunia bisnis. Setiap perusahaan berusaha untuk menjadi yang terdepan dalam sebuah bidang usaha dengan berbagai caranya masing-masing. Berbagai macam strategi diterapkan oleh suatu perusahaan baik perusahaan jasa maupun manufaktur. Salah satunya adalah strategi pemasaran yaitu product (produk), price (harga), place (tempat), promotion (promosi) (Assauri, 2011). Perusahaan perlu mengetahui dimana letak kekurangan atau kelebihan penerapan strategi bauran pemasaran yang sudah dilakukan.

Kebutuhan dan keinginan konsumen selalu mengalami perubahan bahkan cenderung meningkat dari waktu ke waktu maka perusahaan perlu mengadakan suatu riset pemasaran dalam usahanya untuk mengetahui produk apa yang sebenarnya dibutuhkan dan diinginkan oleh konsumen. Konsumen dalam mengambil keputusan untuk membeli suatu produk yang ditawarkan banyak 
dipengaruhi oleh persepsinya terhadap price, product, promotion, place yang telah diterapkan oleh perusahaan selama ini (Kotler, 2005).

Kotler dan Keller (2009) mendefinisikan produk sebagai sesuatu yang dapat ditawarkan kepada pasar untuk memuaskan suatu keinginan atau kebutuhan, termasuk barang fisik, jasa, pengalaman, acara, orang, tempat, properti, organisasi, informasi dan ide. Menurut Daryanto (2013) produk adalah segala sesuatu yang dapat ditawarkan ke pasar untuk mendapatkan perhatian, dibeli, dipergunakan atau dikonsumsi dan yang dapat memuaskan keinginan atau kebutuhan. Konsep lain produk adalah apapun yang dapat ditawarkan pada pasar untuk memuaskan keinginan konsumen (Widiyono dan Pakkanna, 2013).

Kualitas produk merupakan salah satu hal yang penting dalam memilih suatu produk. Konsumen menginginkan kualitas produk yang terbaik dalam melakukan keputusan pembelian. Menurut Kotler (2007) kualitas produk (product quality) adalah ciri dan karakteristik suatu barang atau jasa yang berpengaruh pada kemampuannya untuk memuaskan kebutuhan yang dinyatakan atau tersirat. Menurut Shaharudin dkk. (2010) kualitas produk adalah faktor yang paling penting bagi pemilihan masing-masing merek atau model, terutama di lingkungan pasar dimana dengan tingkat persaingan yang ketat dan penetapan harga yang kompetitif. Kualitas mencerminkan semua dimensi penawaran produk yang menghasilkan manfaat bagi konsumen (Yusof, 2013).

Harga merupakan alat pengukur dasar suatu sistem ekonomi karena harga mempengaruhi alokasi faktor-faktor produksi. Harga didasarkan pada nilai bahwa seseorang atau pengusaha bersedia melepaskan barang atau jasa yang dimiliki 
kepada pihak lain (Kotler, 2012). Hubungan harga dengan keputusan pembelian yaitu harga mempengaruhi keputusan konsumen dalam melakukan pembelian, semakin tinggi harga, maka keputusan pembelian rendah, sebaliknya jika harga rendah, maka keputusan pembelian tinggi (Kotler dan Amstrong, 2005). Penelitian yang dilakukan oleh Rajput, et.al. (2012) menunjukkan bahwa harga berpengaruh positif terhadap perilaku membeli di Pakistan. Harga memiliki pengaruh yang besar terhadap konsumen untuk membeli. Setiap konsumen membutuhkan lebih banyak bentuk diskon atau potongan harga dan paket barang dengan harga yang murah.

Promosi juga merupakan hal yang sangat penting dalam mencuri perhatian konsumen. Perusahaan akan dikenal oleh para konsumen itu jika melakukan promosi mengenai perusahaan dan produk yang di tawarkan. Pemilihan sarana promosi harus dipertimbangkan secara matang karena menarik atau tidaknya suatu promosi akan sangat mempengaruhi berhasil atau tidaknya suatu kegiatan pemasaran di dalam suatu perusahaan. Kegiatan promosi adalah segala usaha yang dilakukan oleh penjual untuk memperkenalkan produk kepada calon konsumen untuk membujuk mereka agar membeli serta mengingatkan kembali kepada konsumen lama agar melakukan pembelian ulang. Penelitian yang dilakukan oleh Niazi, et.al. (2012) menunjukkan bahwa promosi merupakan suatu cara komunikasi untuk meyakinkan seseorang untuk mengambil keputusan tentang membeli suatu produk atau jasa dan memberikan informasi kepada konsumen.

Menurut Kotler dan Amstrong (2010), distribusi merupakan seperangkat organisasi yang saling secara aktual melakukan pembelian produk. Konsumen 
sebagai pelaku utama dalam proses pembelian selalu menjadi perhatian produsen. Saluran distibusi untuk suatu barang adalah saluran yang digunakan oleh produsen untuk menyalurkan barang tersebut dari produsen sampai ke konsumen atau pemakai industri (Dharmmesta, 2008).

Pembeli akan tetap kembali datang dan membeli bila konsumen mendapat kepuasan dari kualitas produk atau jasa yang dihasilkan perusahaan. Masalah pemasaran hakekatnya tidak hanya diarahkan untuk memuaskan konsumen melainkan juga ditujukan untuk mempengaruhi keputusan pembelian konsumen, sehingga keputusan pembelian konsumen mempunyai suatu moment yang penting dalam aktivitas perusahaan. Keputusan pembelian merupakan suatu keputusan seseorang dimana dia memilih salah satu dari beberapa alternatif pilihan yang ada (Schiffman dan Kanuk, 2010)

Pesatnya sektor dunia usaha saat ini, membuat para wirausahawan berlomba-lomba untuk membuat sesuatu yang baru, kreatif, inovatif, dan yang terpenting adalah jeli dalam melihat apa yang diinginkan serta dibutuhkan oleh masyarakat, karena konsumen pun sudah semakin kritis dalam membeli suatu produk. Masyarakat menganggap bahwa kamar mandi bukan hanya tempat untuk membersihkan diri dan membuang kotoran, namun juga dapat digunakan sebagai gambaran dari kepribadian penghuni rumah. Masyarakat telah sadar akan pentingnya tampilan kamar mandi di dalam rumah. Kenyamanan dalam kamar mandi juga merupakan bagian yang sangat penting di karenakan kamar mandi merupakan salah satu ruangan yang paling sering digunakan untuk melepaskan 
penat dan lelah dalam sehari-hari. Produk sanitary yang modern dan nyaman sangat diminati dan dibutuhkan oleh masyarakat.

Sanitary adalah hal-hal yang berhubungan dengan penyediaan fasilitas kebersihan yang sehat. Produk sanitary merupakan produk yang sangat dibutuhkan untuk pembangunan properti residensial dan serta komersial. Contoh produk sanitary ialah bathtub, washtafel, toilet dan lain sebagainya (Nita, 2014).

Fenomena akhir-akhir ini yang terjadi di Bali adalah pesat pembangunan sarana hunian seperti hotel, villa, resort, mall dan lainya yang banyak menggunakan produk sanitary yang modern pada fasilitas bathroom guna memberikan kenyamanan bagi para konsumen. Pasar produk sanitary memang sangat terkait dengan perkembangan pasar properti karena setiap penjualan properti pasti diiringi oleh peningkatan permintaan produk-produk sanitary, dimana setiap satu properti yang terjual pasti membutuhkan peralatan sanitary yang mendukung. Dengan demikian terbuka peluang untuk para produsen sanitary menawarkan produk - produk mereka.

Toto merupakan vendor produk sanitary, selain American Standard, Germany Brilliant dan produk lainnya yang telah puluhan tahun bercokol di Indonesia. Masing-masing merek bersaing secara ketat untuk memperoleh konsumen sebanyak-banyaknya dan berusaha mempertahankan konsumennya agar tidak beralih ke produk sanitary lain.

Kehadiran merk Toto di Indonesia tentu membuktikan bahwa kiprah perusahaan asal Jepang tersebut telah memiliki pengalaman hebat dalam menentukan kualitas produk yang diinginkan oleh konsumen, khususnya di 
Indonesia. Produk-produk dari Toto ini mengutamakan kualitas akan produk yang di buat untuk memenuhi keinginan konsumen yang semakin berkembang dan bertambah. Berbagai macam produk Toto yang di pasarkan diantaranya toilet, urial, wastafel, sink dan bathub. Dari varian yang ada produk Toto mempunyai banyak kelebihan dari produk pesaingnya, untuk mendapatkan produk Toto memerlukan biaya yang cukup mahal. Akan tetapi produk Toto terkenal cukup mahal banyak orang tetap membeli produk tersebut. Hal ini disebabkan Toto merupakan merek yang sudah di kenal dari segi kualitas yang baiik sehingga konsumen tetap membeli produk tersebut (Adirama, 2012).

Persaingan yang terjadi dalam teknologi produk sanitary sangat ketat, di mana para produsen merek sanitary saling berusaha mengikuti perubahan atau perkembangan teknologi yang sudah diterapkan merek pesaing. Toto adalah brand yang kuat dalam bidang produk sanitary dimana merek Toto masih tetap unggul dengan kualitas dan kebesaran nama produk Toto itu sendiri yang mengalahkan para pesaingnya. Dibandingkan dengan produk sanitary lainya harga produk merek toto terbilang cukup mahal dikarenakan bahan-bahan yang di gunakan berkualitas. Ini menjadi celah bagi para pesaing produk merek Toto (Tryono dkk, 2015).

Pra survey yang telah dilakukan menunjukkan bahwa responden menyatakan tetap ingin membeli produk Toto karena telah dianggap sebagai salah satu solusi dalam kebutuhan sanitary modern. Namun, ada beberapa aspek dirasa kurang memuaskan, seperti kualitas produk yang kurang awet, harga cukup mahal, iklan produk kurang menarik, dan pendistribusian produk kurang luas. 
Menurut penelitian yang dilakukan oleh Yani (2014) variabel produk, promosi, harga, dan lokasi berpengaruh signifikan terhadap keputusan pembelian. Sedangkan penelitian yang dilakukan oleh Anggriawan (2017) menunjukan bahwan variabel produk, promosi, distribusi dan harga berpengaruh negatif signifikan namun secara berturut-turut variabel produk memiliki nilai pernyataan negatif tertinggi.

Berdasarkan latar belakang masalah yang telah dipaparkan, pokok permasalahan dalam penelitian ini adalah 1) Bagaimanakah pengaruh kualitas produk terhadap keputusan pembelian produk merek Toto, 2) Bagaimanakah pengaruh harga terhadap keputusan pembelian produk merek Toto, 3) Bagaimanakah pengaruh promosi terhadap keputusan pembelian produk merek Toto, 4) Bagaimanakah pengaruh distribusi terhadap keputusan pembelian produk merek Toto.

Tujuan yang ingin diperoleh dalam penelitian ini adalah 1) Untuk menjelaskan pengaruh kualitas produk terhadap keputusan pembelian produk merek toto di Kota Denpasar, 2) Untuk menjelaskan pengaruh harga terhadap keputusan pembelian produk merek toto di Kota Denpasar, 3) Untuk menjelaskaan pengaruh promosi terhadap pembelian produk merek toto di Kota Denpasar, 4) Untuk menjelaskaan pengaruh distribusi terhadap keputusan pembelian produk merek Toto di Kota Denpasar.

Penelitian yang dilakukan oleh Amanah (2010) menunjukan bahwa variabel kualitas produk berpengaruh positif dan signifikan terhadap keputusan pembelian. Hasil penelitian Nguyen et all (2015) menunjukan bahwa kualitas 
produk memiliki pengaruh positif dan signifikan terhadap keputusan pembelian konsumen. Kualitas produk adalah proses yang berkesinambungan dari perbaikan kinerja produk dan akibatnya kepada kepuasan kebutuhan konsumen, kualitas harus terus ditingkatkan (Tariq et all, 2013). Hasil yang sama juga disebutkan oleh penelitian Susanto (2010) yang juga memperlihatkan bahwa kualitas produk memiliki pengaruh positif dan signifikan terhadap keputusan pembelian. Selanjutnya, hasil penelitian yang dilakukan oleh Iswayanti (2010) yang memperlihatkan bahwa kualitas produk memiliki pengaruh positif dan signifikan terhadap keputusan pembelian. Berdasarkan dari beberapa penelitian sebelumnya yang telah dipaparkan diatas maka dapat dirumuskan hipotesis sebagi berikut:

$\mathrm{H}_{1}$ : Kualitas produk berpengaruh positif terhadap keputusan pembelian

Penelitian yang dilakukan oleh Aswan (2013) memperlihatkan bahwa harga memiliki pengaruh positif dan signifikan terhap keputusan pembelian. Penelitian yang dilakukan oleh Faisal (2013) menunjukan bahwa harga berpengaruh positif dan signifikan terhadap keputusan pembelian. Dawood (2015) memperlihatkan bahwa variabel harga memiliki pengaruh positif dan signifikan terhadap keputusan pembelian. Selanjutnya, penelitian yang dilakukan oleh Yusup (2010) menunjukan bahwa harga berpengaruh positif dan signifikan terhadap keputusan pembelian. Penelitian yang dilakukan oleh Hariadi (2013) menunjukan bahwa variabel harga berpengaruh positif dan signifikan terhadap variabel keputusan pembelian konsumen. Berdasarkan dari beberapa penelitian sebelumnya yang telah dipaparkan diatas maka dapat dirumuskan hipotesis sebagi berikut:

$\mathrm{H}_{2}$ : Harga berpengaruh positif terhadap keputusan pembelian 
Penelitian yang dilakukan oleh Hersona (2013) memperlihatkan bahwa promosi memiliki pengaruh positif dan signifikan terhadap keputusan pembelian. Hasil yang sama juga dikemukakan oleh hasil penelitian Rosita (2010) yang menunjukan bahwa promosi memiliki pengaruh positif dan signifikan terhadap keputusan pembelian. Hasil penelitian Galih (2015) menunjukan bahwa variabel promosi memiliki pengaruh positif dan signifikan tethadap keputusan pembelian konsumen. Hasil penelitian Anggitan (2013) memperlihatkan bahwa promosi memiliki pengaruh positif dan signifikan terhadap keputusan pembelian. Andreti et all (2013) menunjukan bahwa promosi memiliki pengaruh positif dan signifikan tethadap keputusan pembelian konsumen. Hal tersebut menunjukkan bahwa promosi mampu meningkatkan sikap konsumen dalam keputusan pembelian. Berdasarkan dari beberapa penelitian sebelumnya yang telah dipaparkan diatas maka dapat dirumuskan hipotesis sebagi berikut:

$\mathrm{H}_{3}$ : Promosi berpengaruh positif terhadap keputusan pembelian

Saluran distribusi yang pendek sangat memungkinkan untuk dilakukan karena produk memerlukan tingkat layanan yang tinggi. Penelitian yang dilakukan oleh Fatonah (2010) memperlihatkan bahwa distribusi memiliki pengaruh positif dan signifikan terhadap keputusan pembelian. Hasil yang sama juga di kemukakan oleh Susanto (2013) yang menunjukan bahwa distribusi memiliki pengaruh positif dan signifikan terhadap keputusan pembelian. Hasil penelitian Sukotjo dan Radix (2010) juga menunjukan bahwa place memiliki pengaruh yang signifikan terhadap keputusan pembelian. Lizbeth (2012) menunjukan bahwa distribusi memiliki pengaruh positif dan signifikan terhadap 
keputusan pembelian. Selanjutnya, penelitian yang dilakukan oleh Rezky et all (2012) yang menunjukan bahwa distribusi berpengaruh positif dan signifikan terhadap keputusan pembelian. Hal tersebut menunjukkan bahwa distribusi mampu meningkatkan sikap konsumen dalam keputusan pembelian. Berdasarkan dari beberapa penelitian sebelumnya yang telah dipaparkan diatas maka dapat dirumuskan hipotesis sebagi berikut:

$\mathrm{H}_{4}$ : Distribusi berpengaruh secara positif terhadap keputusan pembelian

Berdasarkan penelusuran pada kajian pustaka tentang variabel penelitian dan hipotesis yang digunakan, maka model penelitian yang di bandingkan dalam penelitian ini dapat digolongkan pada penelitian asosiatif, yaitu penelitian yang bertujuan untuk mengetahui pengaruh dari satu variabel, dua variabel, atau lebih (Sugiyono, 2010). Metode ini digunakan untuk mengetahui hubungan antara variabel kualitas produk, harga, promosi, tempat dan keputusan pembelian.

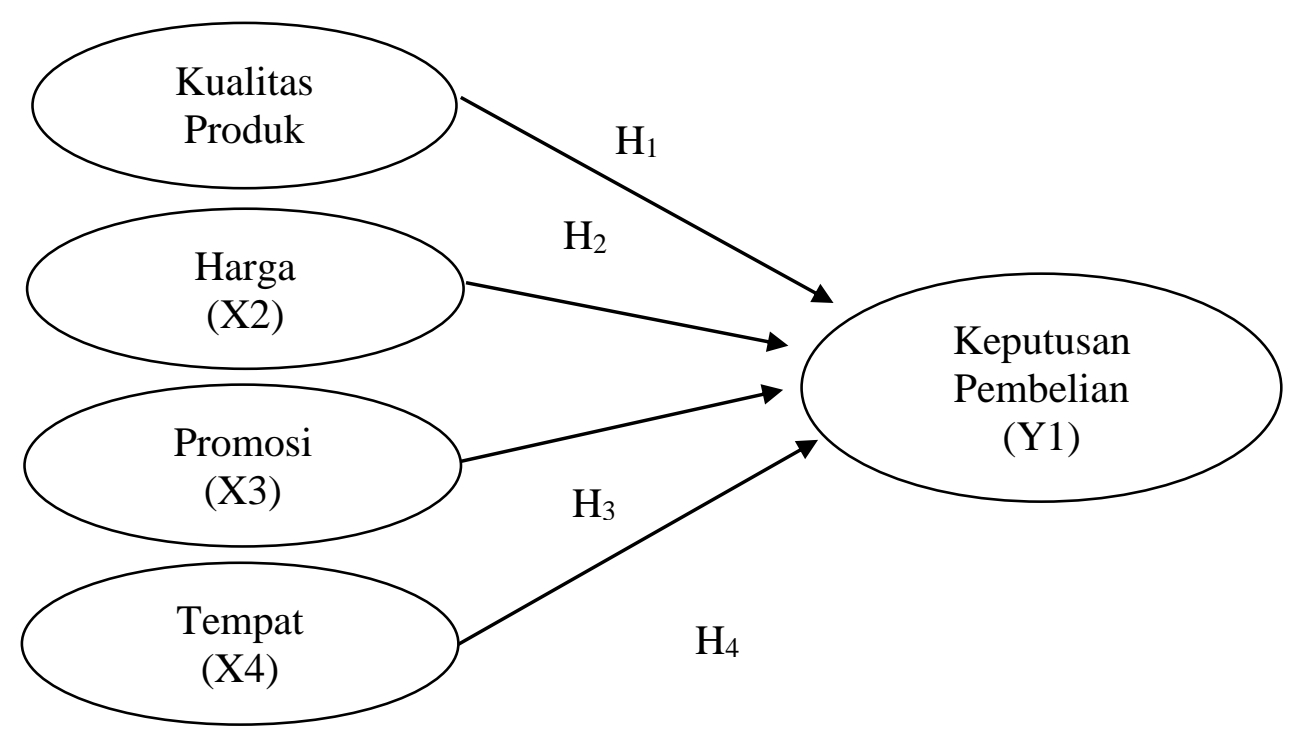

Gambar 1. Model Konseptual Penelitian

Sumber: Data Diolah, 2017 


\section{METODE PENELITIAN}

Penelitian ini dilakukan di Kota Denpasar, lokasi ini dipilih karena pesatnya pembangunan sarana hunian seperti hotel, mall, dan lainya yang banyak menggunakan produk sanitary. Maka peneliti tertarik untuk meneliti mengenai kualitas produk, harga promosi dan distribusi terhadap keputusan pembelian konsumen di Kota Denpasar. Objek dalam penelitian ini adalah perilaku konsumen khususnya dalam kualitas produk, harga, promosi, dan distribusi yang dipengaruhi oleh variabel keputusan pembelian produk Toto.

Berdasarkan pada pokok masalah yang telah dirumuskan serta hipotesis diajukan, maka variabel-variabel daalam penelitian ini adalah sebagai berikut. Variabel terikat (dependent variabel) merupakan variabel yang tergantung dari variabel lain. Variabel terikat dalam penelitian ini adalah keputusan pembelian produk merek toto di Denpasar (Y). Variabel bebas (independent variabel) merupakan variabel yang dapat mempengaruhi variabel lain. Variabel bebas dalam penelitian ini adalah kualitas produk $\left(\mathrm{X}_{1}\right)$, Harga $\left(\mathrm{X}_{2}\right)$, Promosi $\left(\mathrm{X}_{3}\right)$ dan Tempat $\left(\mathrm{X}_{4}\right)$.

Jenis dan sumber data dalam penelitian ini yaitu data kualitatif dan data kuantitatif. Data kualitatif dalam penelitian ini yang dimaksud dengan data kualitatif adalah seperti pendapat responden terhadap pernyataan yang meliputi; kualitas produk, harga, promosi, tempat dan keputusan pembelian. Data kuantitatif dalam penelitian ini berupa data penjualan Toto, dan data yang diperoleh dari kuesioner antara lain: data kualitas produk, harga, promosi, distribusi, keputusan pembelian yang dikualifikasikan dengan memberikan skor jawaban responden. 
Data primer dalam penelitian ini adalah hasil jawaban kuisioner kualitas produk, harga, promosi, distribusi, dan keputusan pembelian produk sanitary ware merek Toto di Kota Denpasar. Data sekunder dalam penelitian ini adalah gambaran untuk perusahaan, dan hasil penelitian sebelumnya.

Populasi dalam penelitian ini adalah konsumen yang pernah melakukan pembelian dan menggunakan produk Toto di Kota Denpasar. Sampel dalam penelitian diambil dengan teknik non probability sampling. yaitu teknik pengambilan sampel yang tidak memberi peluang atau kesempatan sama bagi setiap unsur atau anggota populasi untuk di pilih menjadi sampel. Teknik pemilihan sampel menggunakan teknik purposive sampling, yaitu penentuan sampel berdasarkan pertimbangan maupun syarat-syarat tertentu. Adapun pertimbangan yang di gunakan dalam pengambilan sampel adalah sebagai berikut 1) Berdomisili di Kota Denpasar 2) Responden telah menyelesaikan pendidikan SMA. Pertimbangan ini di gunakan dengan alasan responden sudah dapat memahami isi dari kuisioner dan memiliki pemahaman yang lebih luas 3) Responden yang pernah membeli, dan menggunakan produk merek Toto.

Menurut Ferdinand (2002) penentuan banyaknya sampel diukur sesuai dengan jumlah parameter yang diestimasi. Berdasarkan dari pedoman tersebut, indikator yang ada di kali 5 sampai 10 jumlah parameter yang di estimasi. Indikator yang digunakan dalam penelitian ini adalah sebanyak 18 indikator, maka jumlah sampel yang dapat digunakan adalah 5 sampai 10 x $18=90$ sampai 180 sampel. Dalam penelitian ini ukuran sampel yang digunakan adalah 100 responden. 
Dalam suatu penelitian, pengumpulan data dilakukan secara hati-hati, sistematis dan cermat, sehingga data yang dikumpulkan harus relevan dengan masalah penelitian yang akan dicari jawabannya sebagai upaya menguji kebenaran hipotesis yang telah di rumuskan. Metode pengumpulan data yang di gunakan dalam penelitian ini adalah sebagai berikut. 1) Kuisioner merupakan teknik pengumpulan data yang dilakukan dengan cara memberi seperangkat pertanyaan atau pernyataan tertulis kepada responden untuk dijawab (Sugiyono, 2012). Dalam penelitian ini, peneliti menyebarkan kuesioner dengan teknik penyebaran langsung bertempat di Toko agen Toto di Denpasar dan secara online melalui web. Pengukuran variabel dilakukan dengan skala likert yang menggunakan metode skoring 1-5. 2) Dokumentasi yaitu teknik dokumentasi dipergunakan untuk mengumpulkan data tentang dokumen-dokumen terkait data yang menunjang proses analisis dalam penelitian ini di Kota Denpasar.

Penelitian ini menggunakan instrumen kuesioner sebagai alat pengumpul data, maka perlu dilakukan uji validitas dan reliabilitas agar kuesioner layak untuk digunakan sebagai sumber data. Uji validitas yaitu menguji valid atau tidaknya instrument penelitian, bila terdapat kesamaan antara data yang terkumpul dengan data yang sesungguhnya terjadi pada objek yang diteliti. Ketentuan suatu instrument dikatakan valid atau sahib apabila memiliki koefisien korelasi Pearson Product Moment (r) > 0,3 dengan alpha sebesar 0,05 (Sugiyono, 2012). Pengujian reliabilitas atau keandalan instrument menunjukkan sejauh mana suatu pengukuran dapat memberikan hasil yang konsisten bila dilakukan pengukuran kembali dengan gejala yang sama. Uji reliablitas dilakukan terhadap instrumen 
dengan koefisien Cronbach's Alpha lebih dari 0,60 maka instrumen yang digunakan reliabel. Untuk menguji reliablititas dilaksanakan dengan bantuan program SPSS (Statistic Package of Social Science) (Sugiyono, 2013).

Analisis ini digunakkan untuk memberikan gambaran atau deskripsi atas data yang dikumpulkan dalam penelitian. Dalam penelitian ini menggunakan angka indeks yang digunakkan untuk mengatahui persepsi umum responden mengenai variabel yang diteliti (Ferdinand, 2006). Mengingat sumber data yang digunakan dari penelitian ini adalah penarikan data primer yang akan mempergunakan kuesioner, maka data yang diperoleh tersebut adalah bersifat kualitatif yang sulit untuk dilakukan perhitungan. Dengan demikian diperlukan suatu cara untuk dapat mengkuantitatifkan data tersebut dengan memberikan skor pada masing-masing jawaban responden. Skala Likert digunakan untuk mengukur sikap, pendapat, dan persepsi seseorang atau sekelompok orang tentang fenomena sosial (Sugiyono, 2014). Sebelum model regresi digunakan untuk menguji hipotesis, maka terlebih dahulu dilakukan uji asumsi klasik, yang meliputi uji normalitas, uji multikolinearitas dan uji heterokedastisitas.

Penelitian ini menggunakan analisis regresi berganda yang digunakan untuk menganalisis suatu variabel terikat yang dipengaruhi lebih dari satu variabel bebas. Analisis regresi linear berganda ini digunakan untuk tujuan penelitian yaitu menganalisis pengaruh kualitas produk, harga, promosi, distribusi dan keputusan pembelian konsumen produk sanitary ware merek Toto di Kota Denpasar. Digunakan program SPSS dalam menganalisis data. Model regresi linear berganda ditunjukkan oleh persamaan sebagai berikut. 
$Y=\alpha+\beta_{1} X_{1}+\beta_{2} X_{2}+\beta_{3} X_{3}+\beta_{4} X_{4}+\varepsilon$

Keterangan :

$\begin{array}{ll}\mathrm{Y} & =\text { Keputusan pembelian } \\ \mathrm{X}_{1} & =\text { Kualitas produk } \\ \mathrm{X}_{2} & =\text { Harga } \\ \mathrm{X}_{3} & =\text { Promosi } \\ \mathrm{X}_{4} & =\text { Distribusi } \\ \alpha & =\text { Konstanta } \\ \beta_{1} \beta_{2} \beta_{3} \beta_{4} & =\text { Koefisien regresi } \\ \varepsilon & =\text { Komponen residual atau eror }\end{array}$

\section{HASIL DAN PEMBAHASAN}

Karakteristik responden penelitian pada pelanggan Toto dilihat dari beberapa kriteria, yaitu : jenis kelamin, usia dan pendidikan terakhir.

Tabel 1.

Karakteristik Responden

\begin{tabular}{|c|c|c|c|c|}
\hline No & Variabel & Klasifikasi & $\begin{array}{l}\text { Jumlah } \\
\text { (orang) }\end{array}$ & $\begin{array}{l}\text { Persentase } \\
(\%)\end{array}$ \\
\hline \multirow{2}{*}{1} & Jenis & $\mathrm{L}$ & 40 & 40 \\
\hline & Kelamin & $\mathrm{P}$ & 60 & 60 \\
\hline Jumlah & & & 100 & 100 \\
\hline \multirow[t]{3}{*}{2} & Usia & $\begin{array}{l}18-25 \\
\text { Tahun }\end{array}$ & 26 & 26 \\
\hline & & $\begin{array}{l}>25-40 \\
\text { Tahun }\end{array}$ & 54 & 54 \\
\hline & & $>40$ Tahun & 20 & 20 \\
\hline Jumlah & & & 100 & 100 \\
\hline \multirow[t]{2}{*}{3} & $\begin{array}{l}\text { Pendidikan } \\
\text { Terakhir }\end{array}$ & SMA/SMK & 48 & 48 \\
\hline & & $\begin{array}{l}\text { Perguruan } \\
\text { Tinggi }\end{array}$ & 52 & 52 \\
\hline Jumlah & & & 100 & 100 \\
\hline
\end{tabular}

Sumber: Toto Indonesia, 2017
Tabel 1 menyatakan bahwa karakteristik responden sebagai berikut. 1)

Berdasarkan Tabel 1 terlihat bahwa responden yang berjenis kelamin laki-laki 
berjumlah 40 orang dengan persentase 40 persen dan responden yang berjenis kelamin perempuan berjumlah 60 orang dengan persentase 60 persen. Ini berarti bahwa pelanggan produk Toto di Kota Denpasar sebagian besar didominasi oleh perempuan. 2) Tabel 1 menunjukkan bahwa responden berusia 18 sampai 25 tahun berjumlah 26 orang dengan persentase 26 persen, responden berusia 25 sampai 40 tahun berjumlah 54 orang dengan persentase 54 persen, dan responden berusia lebih dari 40 tahun berjumlah 20 orang dengan persentase 20 persen. Ini berarti bahwa pelanggan produk Toto di Kota Denpasar sebagian besar berusia 20 sampai 40 tahun. 3) Tabel 1 menunjukkan bahwa responden dengan pendidikan terakhir sarjana sebanyak 52 orang dengan persentase 52 persen, dan responden dengan pendidikan tingkat pendidikan terakhir SMA/Sederajat memiliki jumlah 48 orang dengan persentase 48 persen. Ini berarti bahwa responden dengan jumlah tertinggi terletak pada tingkat pendidikan terakhir sarjana sebanyak 52 orang dengan persentase 52 persen.

Uji validitas yaitu menguji valid atau tidaknya instrument penelitian. Instrumen yang valid berarti alat ukur yang digunakan untuk mendapatkan data (mengukur) itu valid. Valid berarti instrumen tersebut dapat digunakan untuk mengukur apa yang seharusnya diukur. Ketentuan suatu instrument dikatakan valid atau sah apabila memiliki koefisien korelasi Pearson Product Moment (r) > 0,3 dengan alpha sebesar 0,05 (Sugiyono, 2013).

Suatu instrument dikatakan valid jika korelasi antara skor faktor dengan skor total bernilai positif dan nilainya lebih dari 0,30 ( $\mathrm{r}>0,3)$. Tabel berikut menyajikan hasil uji validitas instrumen penelitian. 
Tabel 2.

Hasil Uji Validasi

\begin{tabular}{llll}
\hline Variabel & Indikator & Koefisien Korelasi & Keterangan \\
\hline Kualitas Produk $\left(\mathrm{X}_{1}\right)$ & $\mathrm{X}_{1.1}$ & 0,829 & Valid \\
& $\mathrm{X}_{1.2}$ & 0,826 & Valid \\
& $\mathrm{X}_{1.3}$ & 0,883 & Valid \\
& $\mathrm{X}_{1.4}$ & 0,69 & Valid \\
Harga $\left(\mathrm{X}_{2}\right)$ & $\mathrm{X}_{2.1}$ & 0,781 & Valid \\
& $\mathrm{X}_{2.2}$ & 0,924 & Valid \\
& $\mathrm{X}_{2.3}$ & 0,745 & Valid \\
Promosi $\left(\mathrm{X}_{3}\right)$ & $\mathrm{X}_{3.1}$ & 0,828 & Valid \\
& $\mathrm{X}_{3.2}$ & 0,909 & Valid \\
& $\mathrm{X}_{3.3}$ & 0,777 & Valid \\
Tempat $\left(\mathrm{X}_{4}\right)$ & $\mathrm{X}_{4.1}$ & 0,891 & Valid \\
Sumber: Data Diolah, 2017 & & &
\end{tabular}

Hasil uji validitas pada tabel diatas menunjukkan bahwa seluruh variabel memiliki nilai koefisien korelasi dengan skor total seluruh item pernyataan lebih dari 0,30 . Hal ini menunjukkan bahwa butir-butir pernyataan dalam instrument penelitian tersebut valid.

Suatu instrument dikatakan reliabel, jika instrument tersebut memiliki nilai Alpha Cronbach lebih dari 0,60. Hasil dari uji reliabilitas dapat ditunjukkan pada tabel berikut.

Tabel 3.

Hasil Uji Reliabilitas

\begin{tabular}{|c|c|c|c|}
\hline No. & Variabel & Cronbach's Alpha & Keterangan \\
\hline 1 & $\begin{array}{ll}\text { Kualitas } & \text { Produk } \\
\left(\mathrm{X}_{1}\right) & \end{array}$ & 0,816 & Reliabel \\
\hline 2 & Harga $\left(\mathrm{X}_{2}\right)$ & 0,834 & Reliabel \\
\hline 3 & Promosi $\left(\mathrm{X}_{3}\right)$ & 0,841 & Reliabel \\
\hline 4 & Tempat $\left(\mathrm{X}_{4}\right)$ & 0,861 & Reliabel \\
\hline 6 & $\begin{array}{l}\text { Keputusan } \\
\text { Pembelian (Y) }\end{array}$ & 0,781 & Reliabel \\
\hline
\end{tabular}

Sumber: Data Diolah, 2017

Hasil uji reliabilitas yang disajikan dalam Tabel 3 menunjukkan bahwa seluruh instrumen penelitian memiliki koefisien Cronbach's Alpha lebih dari 
0,60. Hal ini dapat dikatakan bahwa semua instrumen reliabel sehingga dapat digunakan untuk melakukan penelitian.

Untuk menguji reliablititas dilaksanakan dengan bantuan program SPSS. Uji ini bertujuan untuk mengetahui apakah residual dari model regresi yang dibuat berdistribusi normal atau tidak. Pengujian apakah data yang digunakan normal atau tidak dapat dilakukan dengan menggunakan uji Kolmogorov Sminarnov, apabila koefisien Asymp. Sig. (2-tailed) lebih dari 0,05 maka data tersebut dikatakan berdistribusi normal.

Tabel 4.

Hasil Uji Normalitas

\begin{tabular}{ll}
\hline & Unstandardized Residual \\
$\mathrm{N}$ & 100 \\
Kolmogorov-Smirnov Z & 0,533 \\
Asymp.Sig.(2-tailed) & 0,939 \\
\hline Sumber: Data Diolah, 2017 &
\end{tabular}

Berdasarkan Tabel 4 dapat dilihat bahwa nilai Kolmogorov Smirnov (K-S) sebesar 0,533, sedangkan nilai Asymp. Sig. understandardized residual (2-tailed) sebesar 0,939. Hasil tersebut mengindikasikan bahwa model persamaan regresi tersebut berdistribusi normal karena nilai Asymp. Sig. understandardized residual (2-tailed) 0,939 lebih dari nilai alpha 0,05.

Uji multikolinearitas dimaksudkan untuk membuktikan atau menguji ada atau tidaknya hubungan yang linier (multikolinearitas) antara variabel bebas (independent) satu dengan variabel bebas yang lain (Sudarmanto, 2005). Uji ini bertujuan untuk menguji apakah pada model regresi ditemukan adanya korelasi antar variabel bebas. Multikolinearitas dapat dilihat dari nilai tolerance atau 
variance inflation factor (VIF). Jika nilai tolerance lebih dari 10 persen atau VIF Kurang dari 10, maka dikatakan tidak ada multikolinearitas.

Tabel 5.

Hasil Uji Multikolinearitas

\begin{tabular}{lll}
\hline Variabel & Tolerance & VIF \\
\hline Kualitas Produk $\left(\mathrm{X}_{1}\right)$ & 0,623 & 1,604 \\
Harga $\left(\mathrm{X}_{2}\right)$ & 0,492 & 2,031 \\
Promosi $\left(\mathrm{X}_{3}\right)$ & 0,694 & 1,44 \\
Tempat $\left(\mathrm{X}_{4}\right)$ & 0,542 & 1,846 \\
\hline Sumber: Data Diolah, 2017 & &
\end{tabular}

Berdasarkan Tabel 5 dapat dilihat bahwa nilai tolerance dan VIF dari seluruh variabel tersebut menunjukkan bahwa nilai tolerance untuk setiap variabel lebih besar dari 10 persen dan nilai VIF kurang dari 10 yang berarti model persamaan regresi bebas dari multikolinearitas.

Uji ini bertujuan untuk mengetahui apakah dalam model regresi terjadi ketidaksamaan varians dari residual satu pengamatan ke pengamatan lain yang dilakukan dengan uji Glejser. Jika tidak ada satu pun variabel bebas yang berpengaruh signifikan terhadap nilai absolute residual atau nilai signifikansinya di atas 0,05 maka tidak mengandung gejala heteroskedastisitas.

Tabel 6. Hasil Uji Heteroskedastisitas

\begin{tabular}{|c|c|c|c|c|c|c|}
\hline \multirow{2}{*}{ Model } & & \multicolumn{2}{|l|}{$\begin{array}{l}\text { Unstandardized } \\
\text { Coefficients }\end{array}$} & \multicolumn{3}{|c|}{$\begin{array}{l}\text { Standardized } \\
\text { Coefficients }\end{array}$} \\
\hline & & B & $\begin{array}{l}\text { Std. } \\
\text { Error }\end{array}$ & Beta & $\mathrm{T}$ & Sig. \\
\hline \multirow{5}{*}{1} & (Constant) & 2.759 & 1.009 & & 2.735 & .007 \\
\hline & $\begin{array}{l}\text { Kualitas } \\
\text { Produk }\end{array}$ & -.085 & .065 & -.167 & -1.312 & .193 \\
\hline & Harga & .067 & .090 & .106 & .743 & .459 \\
\hline & Promosi & -.008 & .079 & -.013 & -.104 & .917 \\
\hline & Tempat & -.070 & .076 & -.127 & -.929 & .355 \\
\hline
\end{tabular}

Sumber: Data Diolah, 2017 
Pada Tabel 6 dapat dilihat bahwa nilai Signifikansi dari variabel Kualitas produk, harga, promosi, dan tempat masing-masing sebesar 0,$193 ; 0,459 ; 0,917$ dan 0,355. Nilai tersebut lebih dari 0,05 yang berarti tidak terdapat pengaruh antara variabel bebas terhadap absolute residual. Dengan demikian, model yang dibuat tidak mengandung gejala heteroskedastisitas.

Pengujian data dalam penelitian ini menggunakan teknik analisis regresi berganda. Dapat dilihat hasil analisis regresi pada Tabel 7.

Tabel 7.

Hasil Analisis Regresi Berganda

\begin{tabular}{|c|c|c|c|c|c|c|c|}
\hline \multirow{2}{*}{ Model } & & \multicolumn{3}{|c|}{ Unstandardized Coefficients } & \multirow{2}{*}{$\begin{array}{l}\text { Standardized } \\
\text { Coefficients } \\
\text { Beta }\end{array}$} & \multirow[b]{2}{*}{$\mathrm{T}$} & \multirow[b]{2}{*}{ Sig. } \\
\hline & & $\mathrm{B}$ & & $\begin{array}{l}\text { Std. } \\
\text { Error }\end{array}$ & & & \\
\hline \multirow{5}{*}{1} & (Constant) & 2.613 & & 1.615 & & 1.618 & .109 \\
\hline & $\begin{array}{l}\text { Kualitas } \\
\text { Produk }\end{array}$ & .230 & & .104 & .187 & 2.212 & .029 \\
\hline & Harga & .399 & & .145 & .261 & 2.754 & .007 \\
\hline & Promosi & .483 & & .127 & .303 & 3.797 & .000 \\
\hline & Tempat & .282 & & .121 & .211 & 2.329 & .022 \\
\hline \multicolumn{2}{|c|}{ R Square } & & $\mathbf{0 , 5 7 9}$ & & & & \\
\hline \multicolumn{2}{|c|}{ F Statistik } & & 32,636 & & & & \\
\hline \multicolumn{2}{|c|}{ Signifikansi } & & $\mathbf{0}$ & & & & \\
\hline
\end{tabular}

Berdasarkan hasil analisis regresi berganda seperti yang disajikan pada tabel 7, maka persamaan strukturalnya adalah sebagai berikut :

$$
\begin{gathered}
Y=\alpha+\beta_{1} X_{1}+\beta_{2} X_{2}+\beta_{3} X_{3}+\beta_{4} X_{4}+e \\
Y=2,613+0,230 X 1+0,399 X 2+0,483 X 3+0,282 X 4
\end{gathered}
$$

Berdasarkan persamaan regresi tersebut, mengandung makna bahwa $\beta_{1}$ : Nilai koefisien Beta untuk variabel kualitas produk sebesar 0,230 mengandung arti bahwa jika kualitas produk $\left(\mathrm{X}_{1}\right)$ mengalami kenaikan satu satuan, maka keputusan pembelian (Y) akan naik sebesar 0,230. $\beta_{2}$ : Nilai koefisien Beta untuk 
variabel harga sebesar 0,399 mengandung arti bahwa jika promosi $\left(\mathrm{X}_{2}\right)$ mengalami kenaikan satu satuan, maka keputusan pembelian (Y) akan naik sebesar 0,399. $\beta_{3}$; Nilai koefisien Beta untuk variabel promosi sebesar 0,483 mengandung arti bahwa jika promosi $\left(\mathrm{X}_{3}\right)$ mengalami kenaikan satu satuan, maka

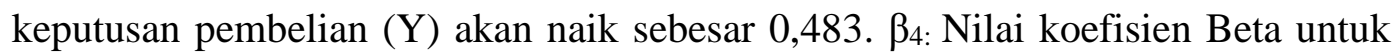
variabel promosi sebesar 0,282 mengandung arti bahwa jika tempat $\left(\mathrm{X}_{4}\right)$ mengalami kenaikan satu satuan, maka keputusan pembelian (Y) akan naik sebesar 0,282.

Tujuan dari penelitian ini salah satunya adalah untuk menjelaskan pengaruh kualitas produk terhadap keputusan pembelian. Berdasarkan hasil analisis pengaruh kualitas produk terhadap keputusan pembelian diperoleh nilai koefisien beta 0,187 dengan Signifikansi sebesar 0,029 $<0,05$ yang berarti $\mathrm{H}_{0}$ ditolak dan $\mathrm{H}_{1}$ diterima. Hal ini mempunyai arti bahwa kualitas produk berpengaruh positif dan signifikan terhadap keputusan pembelian. Hal ini menujukan bahwa semakin baik kualitas produk, maka akan mendorong konsumen untuk membeli produk Toto. Hasil ini sesuai dengan hasil penelitian yang dilakukan oleh Amanah (2010), Ganjar (2013) dan Tariq et al. (2013) menyatakan bahwa kualitas produk memiliki pengaruh positif dan signifikan terhadap keputusan pembelian konsumen.

Penelitian ini salah satunya bertujuan untuk menjelaskan pengaruh harga terhadap keputusan pembelian. Berdasarkan hasil analisis pengaruh harga terhadap keputusan pembelian diperoleh nilai koefisien beta 0,261 dengan nilai Signifikansi sebesar $0,007<0,05$ yang berarti $\mathrm{H}_{0}$ ditolak dan $\mathrm{H}_{1}$ diterima. Hasil 
ini mempunyai arti bahwa harga berpengaruh positif dan signifikan terhadap keputusan pembelian. Hal ini menujukan bahwa penetapan harga produk merek Toto yang dianggap sesuai dengan kualitas dan manfaat produk akan mendorong konsumen untuk membeli produk Toto. Hasil ini sesuai dengan penelitian yang dilakukan oleh Aswan (2013), Faisal (2013) dan Hariadi (2013) menyatakan bahwa variabel harga berpengaruh positif dan signifikan terhadap variabel keputusan pembelian konsumen.

Tujuan dari penelitian ini salah satunya adalah untuk menjelaskan pengaruh distribusi terhadap keputusan pembelian. Berdasarkan hasil analisis pengaruh tempat terhadap keputusan pembelian diperoleh nilai koefisien beta 0,211 dengan nilai signifikansi sebesar $0,022<0,05$ yang berarti $\mathrm{H}_{0}$ ditolak dan $\mathrm{H}_{1}$ diterima. Hasil ini mempunyai arti bahwa distribusi berpengaruh positif dan signifikan terhadap keputusan pembelian. Hal ini menunjukan bahwa semakin luas jalur distribusi yang dilakukan maka konsumen akan mampu menjangkau produk dengan lebih mudah, sehingga akan mendorong keputusan pembelian. Hasil ini sesuai dengan penelitian yang dilakukan oleh Fatonah (2010), Putra (2012) dan Sukotjo dan Radix (2010) menyatakan bahwa place memiliki pengaruh yang signifikan terhadap keputusan pembelian.

Berdasarkan hasil penelitian, diperoleh variabel yang paling dominan adalah promosi dengan nilai standardized coefficients beta sebesar 0,303 . Hasil ini menujukan bahwa Toto harus lebih memperhatikan kefektifan dan menarik dalam mempromosikan produknya. Sehingga semakin menarik dan efektif promosi yang 
diberikan kepada konsumen, maka akan mendorong konsumen untuk memutuskan membeli produk Toto.

\section{SIMPULAN DAN SARAN}

Berdasarkan hasil pembahasan, maka dapat ditarik beberapa simpulan diantaranya bahwa variabel kualitas produk secara parsial berpengaruh positif dan signifikan terhadap keputusan pembelian. Hal ini menunjukan bahwa semakin baik kualitas produk yang diberikan maka akan mendorong konsumen untuk membeli produk Toto. Variabel harga secara parsial berpengaruh positif dan signifikan terhadap keputusan pembelian. Hal ini menunjukan bahwa penetapan harga produk merek Toto yang dianggap sesuai dengan kualitas dan manfaat produk akan mendorong konsumen untuk membeli produk Toto. Variabel promosi secara parsial berpengaruh positif dan signifikan terhadap keputusan pembelian. Hal tersebut menunjukkan bahwa promosi mampu meningkatkan sikap konsumen dalam keputusan pembelian. Variabel tempat secara parsial berpengaruh positif dan signifikan terhadap keputusan pembelian. Hal ini menunjukan bahwa semakin baik dan mudahnya akses distribusi yang dilakukan Toto, sehingga mendorong konsumen untuk memutuskan mebelian produk Toto.

Berdasarkan hasil dan pengolahan penelitian yang telah diperoleh dan temuan yang dihasilkan. Adapun saran yang dapat diberikan yaitu Kualitas produk Toto sudah tergolong baik, sehingga perlu dipertahankan. Meskipun demikian, ada aspek yang perlu ditingkatkan guna lebih mendorong keputusan pembelian pelanggan yaitu dengan mengembangkan inovasi kualitas produk, seperti menggunakan bahan-bahan atau material yang mempunyai daya tahan yang kuat 
dan awet, karena berdasarkan persepsi responden terhadap variabel kualitas produk pada dimensi daya tahan produk mendapatkan skor nilai terendah dibandingkan dimensi kualitas produk yang lain. Harga produk Toto sudah tergolong baik, sehingga perlu dipertahankan. Meskipun demikian, ada aspek yang perlu ditingkatkan guna lebih mendorong keputusan pembelian pelanggan yaitu dengan memperhatikan harga produk Toto dengan produk pesaing, seperti memberikan harga lebih murah agar dapat bersaing dengan penjual produk sejenis. Toto diharapkan memperhatikan pemilihan promosi, karena variabel promosi mempunyai pengaruh yang dominan dalam mempengaruhi struktur keputusan pembelian produk Toto, diantaranya yaitu dengan memberikan sajian iklan produk Toto yang menarik dan potongan harga dari biasanya bagi pelanggan yang berniat berlangganan untuk meningkatkan penjualan produk Toto. Toto diharapkan memperhatikan dan meningkatkan dimensi variabel tempat/distribusi yaitu lokasi strategis, seperti memperluas penyebaran agen Toto agar para konsumen lebih mudah mendapatkan produk sanitary ware Toto di Kota Denpasar.

\section{REFERENSI}

Adirama, Aldi. 2012. Pengaruh Citra Merek dan Kualitas Produk terhadap Keputusan Pembelian sepeda Motor Suzuki Satria Fu. Skripsi Universitas Negeri Yogyakarta.

Ahyari, Agus. 2010. Dasar-dasar Manajemen. Edisi I. Jilid Dua. Yogyakarta: Penerbit BPFE.

Alma, Buchari. 2013. Manajemen Pemasaran dan Pemasaran Jasa. Bandung: Alfabeta. 
Amanah, Dita. 2010. Pengaruh Harga dan Kualitas Produk Terhadap Kepuasan Konsumen Pada Majestyk Bakery dan Cake Shop Cabang H.M.Yamin Medan, Jurnal Keuangan dan Bisnis. 2 (1): 72-74.

Andreti, J., Nabila H., Zhafira, Sheila S, dan Suresh K. 2013. The Analysis of Product, Price, Place, Promotion and Service Quality on Customers Buying Decision of Convenience Store: A Survey of Young Adult in Bekasi West Java. International journal of Advances in Management and Economics, 2 (6): $72-78$.

Anggitan, Rizana. 2013. Analisis Pengaruh Kualitas Produk, Harga dan Promosi Terhadap Loyalitas Pelanggan Dengan Minat Beli Ulang Sebagai Variabel Intervening. Jurnal Manajemen, 7 (9): 1-18.

Assauri, Sofyan. 2011. Manajemen Pemasaran. Jakarta: PT. Raya Grafindo Persada.

Aswan, Hidayat. 2013. Analisis Pengaruh Kualitas Produk, Promosi dan Persepsi Harga Terhadap Minat Bell Ulang Pelanggan Voucher Isi Ulang XL di Universitas Semarang. Jurnal Fakultas Ekonomi Universitas Semarang. 2 (5): 59-78.

Daryanto. 2013. Manajemen Pemasaran. Bandung: Cetakan II. PT. Sarana Tutorial Nurani Sejahtera.

Dawood, D., Khan. 2015. Impact of Marketing Mix On Consumer Buying Behavour In Organic Product Bharathiar University. International Journal of Research in Finance and Marketing, 6 (10): 43-54.

Dharmesta. 2008. Manajemen Pemasaran Modern. Yogyakarta: Edisi Kedua, Liberty.

Faisal. 2013. Pengaruh Citra Merek, Kuualitas Produk, dan Harga Terhadap Keputusan Pembelian Ulang Handphone Jenis Android di Magelang. Jurnal Majemen Pemasaran, 1 (2): 66-69.

Ferdinand, Augusty. 2002. Structural Equation Modelling dalam Penelitian Manajemen. Semarang: FE UNDIP. 
Fitzsimmons, James A, and Mona J. Fitzsimmons, 1994. Service Management for Competitive Advantage, New York: Mc. Graw Hill International Edition, 1994.

Gaspersz, Vincent. 2005. Sistem Manajemen Kinerja Terintegrasi Balanced Scorecard Dengan Six Sigma Untuk Organisasi Bisnis dan Pemeritah. Jakarta: Gramedia Pustaka Utama.

Ghozali, Imam. 2013. Aplikasi Analisis Multivariate dengan Program SPSS. Yogyakarta: Badan Penerbit BPFE.

Ghulam, Shabbir Khan Niazi, Javaria Siddiqui, Burhan Ali Shah, and Ahmed Imran Hunjra. 2012. Effective Advertising and its Influence on Consumer Buying Behavior. Information Management and Business Revie, 4 (3): 114119

Hariadi, D., dan Soebari M. 2013. Pengaruh Produk, Harga, Promosi dan Distribusi Terhadap Keputusan Pembelian Konsumen Pada Produk Projector Microvision. Jurnal Ilmu dan Riset Manajemen, 3 (2): 70-71.

Hendri, S., dan Sumanto, R. 2010. Analisa Marketing Mix-7P (Product, Price, Promotion, Place, Partisipant, Process, dan Physical Evidence) Terhadap Keputusan Pembelian Produk Klinik Kecantikan Teta di Surabaya. Jurnal Mitra Ekonomi dan Manajemen Bisnis, 1 (2): 216-228.

Hersona, S., dan Asep M. 2013. Analisis Pengaruh Bauran Promosi Terhadap Keputusan Pembelian Jasa di Lembaga Pendidikan Speaking Karawang. Jurnal Manajemen, 10 (3): 37- 60

Husein, U. 2010. Riset Pemasaran dan Bisnis, Jakarta: Gramedia Pustaka Utama.

Ika, Iswani. 2010. Analisis Pengaruh Kualitas Produk, Kualitas Layanan, Harga dan Tempat Terhadap Keputusa Pembelian Studi pada Rumah Makan Soto Angkring Mas Boed di Semarang Skripsi Universitas Diponegoro.

Kodu, S. 2013. Pengaruh Harga, Kualitas Produk dan Kualitas Pelayanan Pengaruhnya Terhadap Keputusan Pembelian Mobil Toyota Avanza. Jurnal EMBA, 1(3): 1251-1259

Kotler, P., and Kevin L., K. 2012. Marketing Management. New Jersey: Pearson Prentice Hall, Inc. 
------- 2009. Manajemen Pemasaran. Jakarta: Jilid 1. Edisi Ke dua belas. Indeks.

2009. Manajemen Pemasaran. Jakarta: Edisi Ketiga belas. Jilid1 dan 2. Cetakan Keempat. PT. Indeks.

-------- 2010. Manajemen Pemasaran, Jakarta: Penerbit Prehallindo.

Kosasih. 2013. Pengaruh Perilaku Konsumen Terhadap Keputusan Pembelian Sepeda Motor Yamaha di Dealer Arista Johar. Jurnal Manajemen, 10 (13): 1125-1148

Lupiyoadi. 2009. Manajemen Pemasaran Jasa, Jakarta: Penerbit Salemba Empat.

Lizbeth, Salgado. 2012. Marketing Mix Influencing Organic Foods Purchase of Mexican Consumers Beltrán University of Sonora, Mexico. International journal, 28 (4): 993-1006

Mandey, J., Bernadette. 2013. Promosi, Distribusi, Harga Pengaruhnya Terhadap Keputusan Pembelian Rokok Surya Promild. Jurnal EMBA. 15(4): 303-344

Marwan, A. 2011. Marketing Businnes. Yogyakarta: Penerbit Liberty.

Murwatiningsih, 2014. Marketing Mix Toward Purchasing Decision Empowering The Counsumers. International Journal of Business, Economics and Law, 4 (1): 289-302

Ninh N., Thi T., and Phuong A. 2015. The Impact of Marketing Mix Elements on Food Buying Behavior: A Study of Supermarket Consumers in Vietnam International Journal of Business and Management, 10 (10): 206-224

Purna, R., Huam H., Amran R., Thoo A., and Inda S. 2012. The Relationship Between Marketing Mix And Customer Decision Making Over Travel Agents. Journal of Academic Research in Business and Social Sciences, 2 (6): 143-165

Rajput, K., dan Wasif. 2012. Impact of Product Price and Quality on Consumer Buying Behavior: Evidence from Pakistan. Interdisciplinary Journal of Contemporary Research In Business, 4 (4): 585-496. 
Samart, D. 2016. The Marketing Mix Strategy Model to Influencing the Decision to Purchase Ready-to-Drink (RTD) Green Teas among University Students in Bangkok Metropolitan Region, Thailand: International Journal of Sciences: Basic and Applied Research, 9 (1): 90-103

Shallu, and Sangeeta, G. 2013. Impact of Promotional Activities on Consumer Buying Behavior: A Study of Cosmetic Industry. International Journal of Commerce Business and Management, 2 (6): 2319-2828

Siti, F., dan Soebandiono, R. 2010. Analisis Faktor-Faktor Marketing Mix Yang Mempengaruhi Keputusan Konsumen Membeli Benih Jagung Hibrida Pioneer P21 Di Kabupaten Bantul. Jurnal Manajemen, 34 (5): 213-145

Sumarwan, U., Herien, P., Agustinus, H., Mukti, M., Gazali, M., Hartono, S., Tara, F. 2013. Riset Pemasaran dan Konsumen. Bogor: IPB Press.

Sussanto, H. dan Handayani. 2010. Pengaruh Atribut Produk Terhadap Keputusan Handphone Samsung Glaxay Series. UG Jurnal, 7 (5): 17-32. 